\title{
ENTOMOLOGY
}

\section{Brewery's waste streams as a valuable substrate for Black Soldier Fly Hermetia illucens (Diptera: Stratiomyidae)}

\author{
C. Jucker, M.G. Leonardi, I. Rigamonti, D. Lupi, S. Savoldelli \\ Department of Food, Environmental and Nutritional Sciences (DeFENS), University of Milan, Italy
}

\begin{abstract}
The growing population and, consequently, the demand for food, has led to an increase in the agro-food activities, causing irreversible exploitation of natural resources. The use of insects for the management and recycling of by-products of the agro-food industry and for the production of proteins is growing. The Diptera Hermetia illucens is of particular interest as larvae are able to grow rapidly on numerous organic matters and are rich in proteins and fats. The identification of a low-cost and low-impact substrate suitable for the mass rearing of $H$. illucens is conse-
\end{abstract}

Correspondence: Costanza Jucker, Department of Food, Environmental and Nutritional Sciences (DeFENS), Università degli Studi di Milano, Via Celoria 2, 20133 Milan, Italy.

Tel.: +39.02.50316745.

E-mail: costanza.jucker@unimi.it

Key words: brewers'spent grain, trub, biological traits, performances, protein production

Acknowledgments: Authors are grateful to Dr. Marco Palamara and Dr. Giulia Ballerini for their help and thank Birrificio Lambrate s.r.l (Milan, Italy) for the supplying of the brewery's by-products.

Contributions: Conceptualization and design research: CJ, SS; Investigation CJ, SS, MGL, DL; Data curation: CJ, SS, DL; Writingreview and editing: CJ, SS, IR, MGL, DL; Project funding: CJ. All authors agreed to the published version of the manuscript.

Conflict of interest: the authors declare no potential conflict of interests

Funding: the work was supported by the University of Milan within the Project Linea B "Insects: an alternative source of proteins - PROENTO”.

Received for publication: 17 December 2019.

Accepted for publication: 31 December 2019.

${ }^{\circ}$ Copyright: the Author(s), 2019

Licensee PAGEPress, Italy

Journal of Entomological and Acarological Research 2019; 51:8876

doi:10.4081/jear.2019.8876

This article is distributed under the terms of the Creative Commons Attribution Noncommercial License (by-nc 4.0) which permits any noncommercial use, distribution, and reproduction in any medium, provided the original author(s) and source are credited. quently of great interest. In this study, we evaluated the suitability of brewery wastes, spent grain and trub (used separately or mixed), as rearing substrate for the larvae. We evaluated the effect of these diets on preimmaginal performance (survival, developmental time, and weight reached) and adult traits (sex-ratio, dimension, and female fertility). As a result, the different substrates significantly impacted different biological traits. Best results, both for larvae and adults, were reported when the brewery wastes were provided together, leading to similar results obtained in a control diet and comparable to other previous studies. We conclude that brewery by-products can be valuable substrate for larval growth and in this way can be efficiently recycled and valorised.

\section{Introduction}

The increase in the world population and the progressive raising of living standards (United Nations, 2013), determine a continuous growing of agro and food industry activities, that induces in turn an excessive and irreversible exploitation of natural resources and at the same time of the areas dedicated to agricultural production and therefore of food goods (Gibbs et al., 2010). Areas of research even distant by type, found strong points of contact in the solution of contingent problems. One of these is the identification of new and less environmental impacting strategies for food production and the recycling of food waste. In this contest rises the worldwide interest in the rearing of insects on wastes and by-products of the agro and food industry, due to the ability of these animals to convert low-value organic substrates into macromolecules of high nutritional value, in particular proteins and fats (Cappellozza et al., 2019; Fowles \& Nansen, 2019; Varelas, 2019). Hermetia illucens L. (Diptera Stratiomyidae), also known as the black soldier fly, is considered among the insects of particular interest for its nutritional value and its ability to grow on organic substrates of different nature with an efficient reduction, up to $75 \%$, of the waste masses (Newton et al. 2005; Diener et al. 2011; Barragan-Fonseca et al., 2017; Jucker et al. 2017).

Assuming in the areas of high anthropic density many agrofood industries are present and huge quantities of food waste are produced, the use of $H$. illucens to manage and valorise these wastes through their conversion into food, feed or fuel represents a current challenge (Diener et al., 2011; Bava et al., 2019; Lalander et al., 2019). The growing insect industrial production still relies on the use of artificial diets greatly impacting the final cost of the product and increasing the environmental impact (Oonincx \& De Boer, 2012; Bava et al., 2019). Thus, the identifi- 
cation of low-cost and low-impact substrates suitable for the mass rearing of insects is of great interest and can reduce the future competition for grains.

Among numerous agro-food by-products, in this research we considered the waste from the beer production, one of the most consumed alcoholic drinks in the world whose consumption has increased over the past ten years (Filladeau et al., 2006). Despite Italy is one of the countries with the lowest per capita consumption in Europe, beer consumption and production in the country are continuously increasing. In particular, small and micro-breweries increased by $345 \%$ in the last ten years (AssoBirra, 2018). As a result, Italy actually represents the ninth European producer by production volumes and ranks fifth for the number of breweries.

Beer production yields abundant amount of low-cost organic wastes available throughout the year, largely underutilized despite their potential nutritional value, and their disposal entails costs for the brewery (Tang et al., 2009; Robertson et al., 2010). The main waste products of beer brewing are brewers' spent grain, which represents $85 \%$ of the total dry waste and hot trub, characterized by high humidity levels, up to 90\% (Rocha dos Santos et al., 2014; De Marco et al., 2016). The research of alternative utilisation of brewery by-products is still ongoing (Aliyu \& Bala, 2011; Kerby \& Vriesekoop, 2017).

To evaluate the possible use of brewery's wastes in the rearing system of H. illucens, in the present study we assessed the suitability of this waste for the development of the insect. In detail, different biological parameters were used as instrument to evaluate the feasibility of the rearing system on the brewers' spent grain and hot trub produced by a craft-brewery.

\section{Materials and Methods}

Larvae of Hermetia illucens used in the experimental trials came from a laboratory stock culture at the University of Milan. Larvae were reared on hen feed mixed with water $(500 \mathrm{~g} / 800 \mathrm{~mL}$ water) until pupation. Pupae were then placed in containers with wood sawdust; adults emerged were transferred in a cage $(100 \times 80 \times 60 \mathrm{~cm})$ where they mated and laid eggs on corrugated cardboard, positioned on a plastic container $(20 \times 10 \times 5 \mathrm{~cm})$ and filled with hen diet mixed with water as attractant for females (Jucker et al., 2017). Neonate larvae (four-day old), collected from the container, were used for the trials.

\section{Growing substrates and experimental trials}

The substrates (brewer's spent grain and trub) were provided by a craft brewery (Birrificio Lambrate s.r.l, Milan, Italy). Substrates were directly collected from the production process in the brewery. Once collected, the two substrates were separately placed in buckets with lids, then placed in freezer bags $(500 \mathrm{cc})$, and stored at $-18^{\circ} \mathrm{C}$. Before insect feeding, each substrate was placed at room temperature for $24 \mathrm{~h}$.

The following substrates were tested: 1) brewers' spent grain; 2) chopped brewers' spent grain; 3) trub; 4) brewers' spent grain added with trub; 5) standard diet. Brewers' spent grain was tested as it was or chopped with a mixer to test if homogenization was more appreciated by the larvae. Moreover, a mixture in equal parts $(1: 1)$ of the two brewer by-products was tested. A standard diet, composed by $50 \%$ wheat germ, $30 \%$ alfalfa, and $20 \%$ corn flour added with water was used as a control (Jucker et al., accepted). Different diets were added with water, when necessary, to obtain a moisture of $50-60 \%$.

Three replicates per substrate/control were prepared. Replicates consisted of 200 four-days-larvae, placed on the differ- ent substrates in a $500 \mathrm{~mL}$ container with a perforated lid covered with a mesh netting and fed at libitum. Containers were maintained in a climate chamber at $\mathrm{T} 25 \pm 0.5^{\circ} \mathrm{C}$; $\mathrm{RH} 60 \pm 0.5 \%$; light cycle 12:12 L:D.

\section{Biological traits}

To evaluate the growth rate on the different diets, larval weight was measured every three days on a subsample of ten larvae and then returned to their respective container. Feed supply was stopped when $40 \%$ of the larvae reached the prepupal stage in each replicate. Prepupae were removed daily from the trial, counted and put in a separate container with wood shaving waiting for adult emergence. Twenty pupae per replicate were weighted. When adults emerged, they were counted and sexed based on genitalia dimorphism. A sample of 20 males and 20 females for each replicate (a total of 60 for diet) was measured with a caliper, dried at $105^{\circ} \mathrm{C}$ for $48 \mathrm{~h}$, and weighed. All weights were conducted using an analytical balance (Sartorius CP64, accuracy $0.1 \mathrm{mg}$ ).

In order to acquire data on adult performance in terms of fertility, a separate set of 500 larvae was reared on the experimental growing substrates under the same climatic condition. Adults (50 males and 50 females) from the different diets were placed in separate boxes (one for each treatment, $60 \times 40 \times 40 \mathrm{~cm}$ ) at room temperature $\left(25 \pm 0.5^{\circ} \mathrm{C}\right.$ and $\left.30 \pm 0.5 \% \mathrm{RH}\right)$ and egg-laying cardboards were provided in each box in presence of hen diet as female attractant. Cardboard strips ( $2 \mathrm{~mm}$ in width; three flute openings per $\mathrm{cm}$ ) were checked every two days for egg masses (Booth and Sheppard, 1984). Ten egg clutches for each treatment were collected. After weighted, the clutches with the analytical balance, eggs were counted with the help of a counter under the stereomicroscope (Leica MZ 12, Germany).

\section{Statistical analysis}

Experimental data on larval development, final larval and pupal weight, adult weight and length, survival of different stages, weight of egg clutches and number of eggs were compared by oneway analysis of variance (ANOVA). Prior to analyses, all data were examined with Levene's test for homogeneity of variance and with the ShapiroWilk test for normal distribution. Where significant differences occurred, the Tukey-Kramer honestly significant difference (HSD) multiple comparisons test was performed for mean separation $(\mathrm{P}<0.05)$. Moreover, the two-tailed Student's ttest was used to assess significant differences between female and male body weight and length $(\mathrm{P}<0.05)$. The SPSS for Windows statistical package, Version 25.0 (SPSS Inc., Chicago) was used for the statistical analysis.

\section{Results and Discussion}

\section{Preimmaginal stages}

H. illucens was able to feed, survive and complete its life cycle on all the tested diets. Nevertheless, growing substrates significantly impacted its biological traits and the success of the development.

Larval developmental time varied considerably in relation to the diet provided $\left(\mathrm{F}_{4,10}=27.96 ; \mathrm{P}<0.05\right)$ (Table 1; Figure 1$)$ : only the brewers' spent grain mixed with trub was statistically similar to the standard diet, with a mean of $18.7 \pm 0.3$ days to reach the prepupal stage; larvae reared on all the other experimental substrates took longer. Furthermore, when brewers' spent grain was supplied finely chopped larval development period was even greater (mean of $33.0 \pm 2.3$ days). These results are not comparable with the shorter development time reported in other researches where waste streams 
from brewing industry were tested (Chia et al., 2018; Liu et al., 2018; Meneguz et al., 2018). On the contrary, the results are in line with the ones observed when $H$. illucens was reared on other vegetables substrates, such as sorghum, cowpea, a mix of vegetables or fruits (Nguyen et al., 2013; Jucker et al., 2017; Tinder et al., 2017; Barragan-Fonseca et al., 2018). It is well known that the quality of the feeding substrates strongly influences the preimmaginal and adult traits and performance in different insect species (Gobbi et al., 2013; Cammack \& Tomberlin, 2017; Favaro et al., 2017; Tinder et al., 2017; Jucker et al., accepted). In general, slower larval development is observed on low-protein and low-energy diets (e.g. fruits and vegetables), while balanced diets allow an optimal growth. In addition, other authors (Nguyen et al., 2013; Jucker et al., accepted), observed that a high-fat-diet could be detrimental for $\mathrm{H}$. illucens larval growth. The longer larval development time observed in brewers' spent grain could be attributed to the high content of cellulose, ligninocellulose and lignine (Aliyu and Bala, 2011; Mathias et al., 2015; Liu et al., 2018) which affects the time required to complete the larval cycle, the survival rate and the final larval weight (ur Rehman et al., 2017). Instead, the extreme moisture of the trub (nearly $90 \%$, Mathias et al., 2015) could have negatively influenced the duration of the larval development. Holmes et al. (2012) reported that an increase in humidity in the growing substrates up to $70 \%$ promotes larval growth, while the presence of an excessive liquid fraction, as observed in trub, negatively affects larval development (Kalovà \& Borkovcovà, 2013). On the contrary, mixing the two by-products has led to an optimal larval growth, due to the reduction of the liquid fraction thanks to its absorption by brewers' spent grain, and also to a more balanced diet, as the trub protein content is reported in Mathias et al. (2015) as 49\%.

Larval mortality $\left(\mathrm{F}_{4,10}=24.66 ; \mathrm{P}<0.05\right)$ and pupal mortality $\left(F_{4,10}=20.64 ; \mathrm{P}<0.05\right)$ were also significantly affected by the growing substrates (Figure 2). In detail, the feeding on trub alone resulted in the highest larval mortality, while feeding on all other diets produced a high survival comparable with larvae grown on the standard diet. Pupal mortality on the contrary was higher than larval mortality in all the tested diets. Pupae from brewers' spent grain (as it or finely chopped) reached a mortality higher than $46 \%$, leading

Table 1. Duration of larval period (days), final larval weight and pupal weight (g), adult sex ratio on the different growing substrates $($ mean \pm ES).

\begin{tabular}{lcccc} 
& $\begin{array}{c}\text { Larval development } \\
\text { (days) }\end{array}$ & $\begin{array}{c}\text { Final larval weight } \\
(\mathrm{g})\end{array}$ & $\begin{array}{c}\text { Pupal weight } \\
(\mathrm{g})\end{array}$ & $\begin{array}{c}\text { Adult sex ratio } \\
\text { (MaF) }\end{array}$ \\
Brewers' spent grain & $24.7 \pm 0.3^{\mathrm{bc}}$ & $0.860 \pm 0.003^{\mathrm{a}}$ & $0.054 \pm 0.002^{\mathrm{a}}$ & $0.64 \pm 0.05^{\mathrm{a}}$ \\
Chopped spent grain & $33.0 \pm 2.3^{\mathrm{d}}$ & $0.873 \pm 0.007^{\mathrm{a}}$ & $0.064 \pm 0.002^{\mathrm{a}}$ & $0.66 \pm 0.02^{\mathrm{ab}}$ \\
\hline Trub & $28.3 \pm 1.9^{\mathrm{cd}}$ & $0.180 \pm 0.008^{\mathrm{b}}$ & $0.108 \pm 0.003^{\mathrm{b}}$ & $0.96 \pm 0.09^{\mathrm{bc}}$ \\
Brewers' spent grain+trub & $18.7 \pm 0.3^{\mathrm{ab}}$ & $0.244 \pm 0.011^{\mathrm{c}}$ & $0.160 \pm 0.014^{\mathrm{c}}$ & $0.95 \pm 0.09^{\mathrm{ab}}$ \\
\hline Standard diet & $15.3 \pm 0.3^{\mathrm{a}}$ & $0.235 \pm 0.002^{\mathrm{c}}$ & $0.142 \pm 0.002^{\mathrm{c}}$ & $1.02 \pm 0.06^{\mathrm{c}}$
\end{tabular}

Different letters indicate significant differences across diets $(\mathrm{P}<0.05)$.

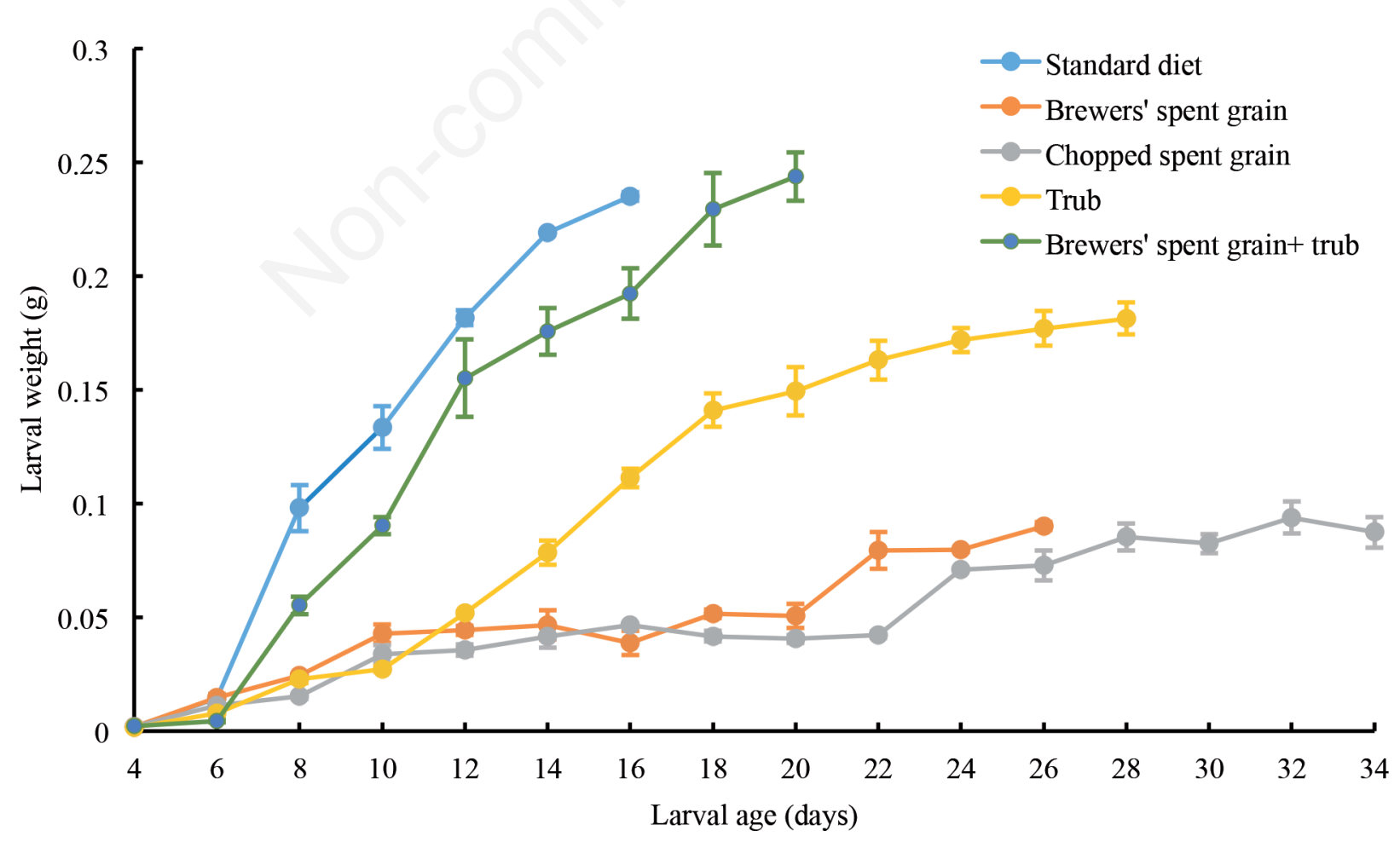

Figure 1. Larval growth on the different experimental substrates. Larvae were weighted until $40 \%$ reached the prepupal stage. 
to a total mortality (from larvae to adult emergence) around $50 \%$. Pupal mortality was lower when trub was added to the diet.

Data on larval survival are in agreement with what reported by Chia et al. (2018) on brewery wastes, and with other authors testing different vegetable or animal wastes (Jucker et al., 2017; Barragan-Fonseca, 2018; Miranda et al., 2019; Jucker et al., accepted), and even higher than what reported by Nguyen et al. (2013) on a wide type of organic resources. Low larval mortality indicates that our tested substrates can efficiently sustain $H$. illucens population development. The high mortality of pupae (in this study reported only on the brewers' spent grain), is not in contrast with this affirmation as similar levels of mortality in pupae were already observed by different authors on H. illucens larvae reared on vegetables, fruits but also on kitchen waste, liver or fish waste (Nguyen et al., 2013; Cammack \& Tomberlin, 2017; Jucker et al., 2017). Chia et al. (2018) registered a pupal mortality up to $35 \%$ on different brewery waste streams.

Final larval weight was significantly different $\left(\mathrm{F}_{4,10}=126.02\right.$; $\mathrm{P}<0.05$ ) among larval diets (Table 1). Individuals fed only with brewer's spent grain were the lightest, with a weight $65 \%$ lower than those on the mixture of the two waste streams. The addition of the trub to the brewers'spent grain greatly increased the final larval weight and no statistical differences were noticed with the standard diet. Trub alone gave intermediate results. Statistical differences were detected also on pupal weight, following the larval trend $\left(\mathrm{F}_{4,295}=47.45 ; \mathrm{P}<0.05\right)$ (Table 1). Pupae coming from the mixture were similar to the standard diet, while when the by-products were provided alone, pupae were lighter, in particular on the brewer's spent grain (as it or chopped). Weight obtained with prepupae reared on trub or on the mixture of trub and brewery are comparable or higher with previous investigations on a similar substrate, which report a prepupal weight of 0.08-0.17 g (Chia et al., 2018; Nyakeri et al., 2017; Meneguz et al., 2018; Bava et al., 2019) and a pupal weight of 0.11-0.15 g (Chia et al., 2018). Also other vegetable wastes resulted in similar larval weight (BarraganFonseca et al., 2018; Jucker et al., 2017; Lalander et al., 2019), while substrates nutritionally richer allow best performance resulting also in heavier larvae (Nguyen et al., 2013; Lalander et al.,
2019; Jucker et al., accepted). In this study, the mixture of the two brewery by-products produced results similar to the standard diet, thanks to its chemical composition, as already stated. The prepupal weight is an important parameter as represents the insect stage usually collected in H. illucens mass rearing for protein production and it shows an optimal nutritional profile (Sheppard et al., 1994; Spranghers et al., 2017; Tomberlin \& Cammack, 2017). Moreover, as prepupae stop feeding, their weight (and that of pupae) is important as it affects, with the nutrients stored by the larval stage, adult weight and performances.

\section{Adults}

Sex ratio (males: females) of the emerged adults was assessed for all experimental treatments and was influenced by the growing diets $\left(\mathrm{F}_{4,10}=7.26 ; \mathrm{P}<0.05\right)$ (Table 1). Sex-ratio was female-biased on brewer's spent grain, provided both as it or chopped. The ratio between males and female was more balanced in all other tested substrates. Barragan-Fonseca et al. (2018) found a sex ratio of 0.93 and 1.22 in trials using different vegetables ingredients for larval growth; Jucker et al. (2017) determined a sex ratio of 0.99 when larvae were fed only on fruits diet, while a male-biased sex-ratio was found on vegetables diet. The proportion between males and females has to be taken in consideration in artificial mass rearing as it has been reported that fertility is influenced by sex ratio. In male-based population, each female lays more eggs than in femaledominant populations due to the lower density of males that delays mating, reducing the size of female oviposition (Hoc et al., 2019). Nevertheless, the total egg production is higher for female-dominant population due to the highest number of females. Thus, considering a $H$. illucens mass production, a slightly female-biased population is strictly recommended (Hoc et al., 2019).

Adult weight (Females: $\mathrm{F}_{4,295}=4033.18 ; \mathrm{P}<0.05$; Males $\mathrm{F}_{4,295}=2344.69 ; \mathrm{P}<0.05$ ) and length (Females: $\mathrm{F}_{4,295}=148.48$; $\mathrm{P}<0.05$; Males $\left.\mathrm{F}_{4,295}=125.54 ; \mathrm{P}<0.05\right)$ were impacted by larval feeding (Figures 3 and 4). Individuals emerged from the brewers' spent grain were lighter and smaller, both for females and males. The mixture of brewers' spent grain and trub provided the highest weight and length for females, even more than the standard diet.

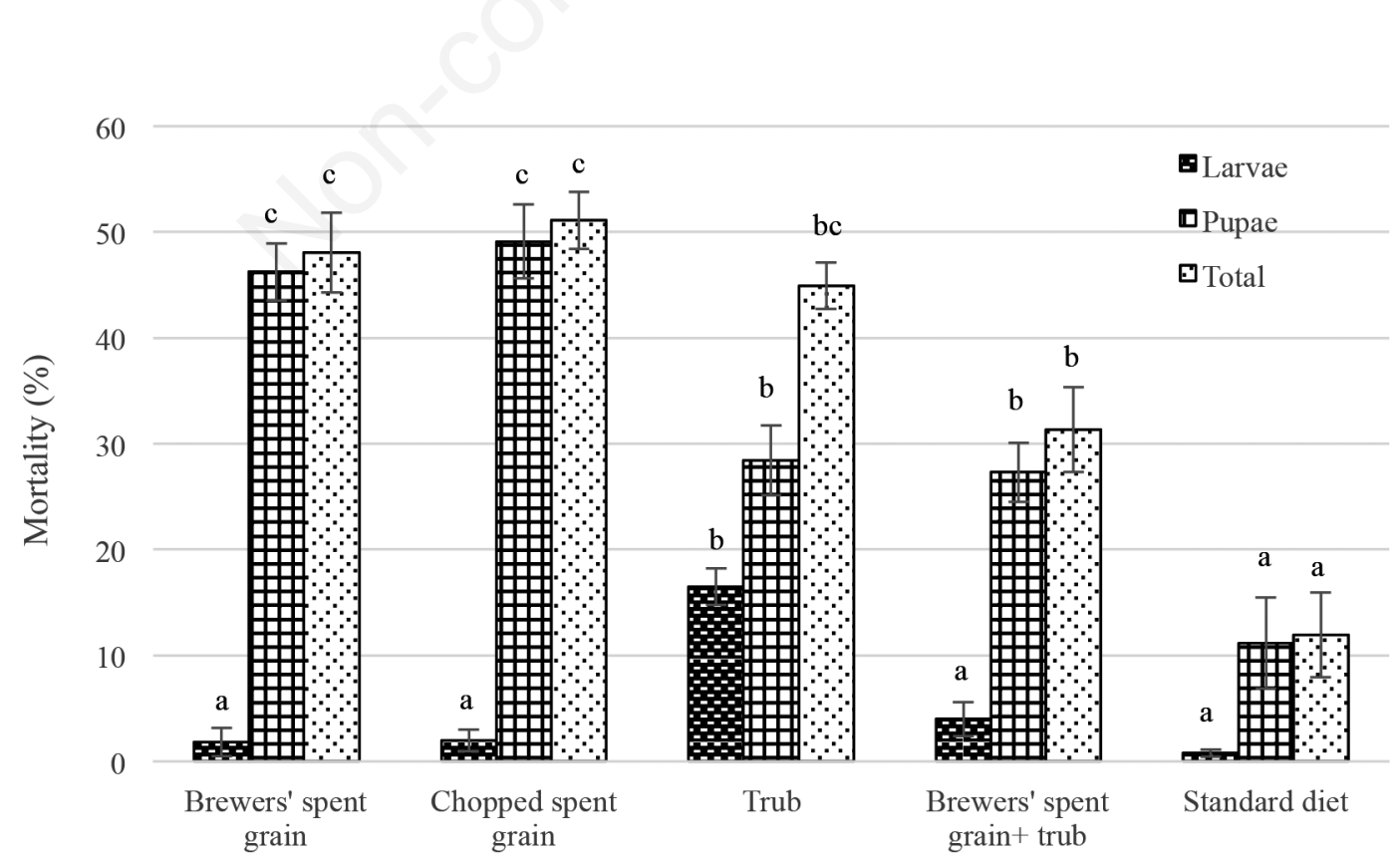

Figure 2. Mortality of $H$. illucens larvae, pupae and total mortality (mean \pm SE). Significant differences among means of the different growing substrates are indicated by different lower case letters (Tukey's test, $\mathrm{P}<0.05$ ). 
Males emerged from the mixture significantly differed from other tested wastes with higher parameters. Trub alone supplied intermediate values. The adult weights strongly reflected the trend already observed in preimmaginal stages. As known, larvae of $H$. illucens are very voracious and accumulate fat body only during the larval stage, while imaginal feeding is less fundamental and mostly influences adult longevity (Nakamura et al., 2016; Lupi et al., 2019).
Comparing the weight of the two sexes, females were heavier than males in all experimental substrates (Figures 3 and 4) $(\mathrm{P}<0.05)$. Females were longer than males except for those emerged from trub and standard diet. This difference in the weight between females and males was already observed by previous authors (Tomberlin et al., 2009; Jucker et al., 2017; Chia et al., 2019; Jones and Tomberlin, 2019; Miranda et al., 2019;). In particular, Tomberlin et

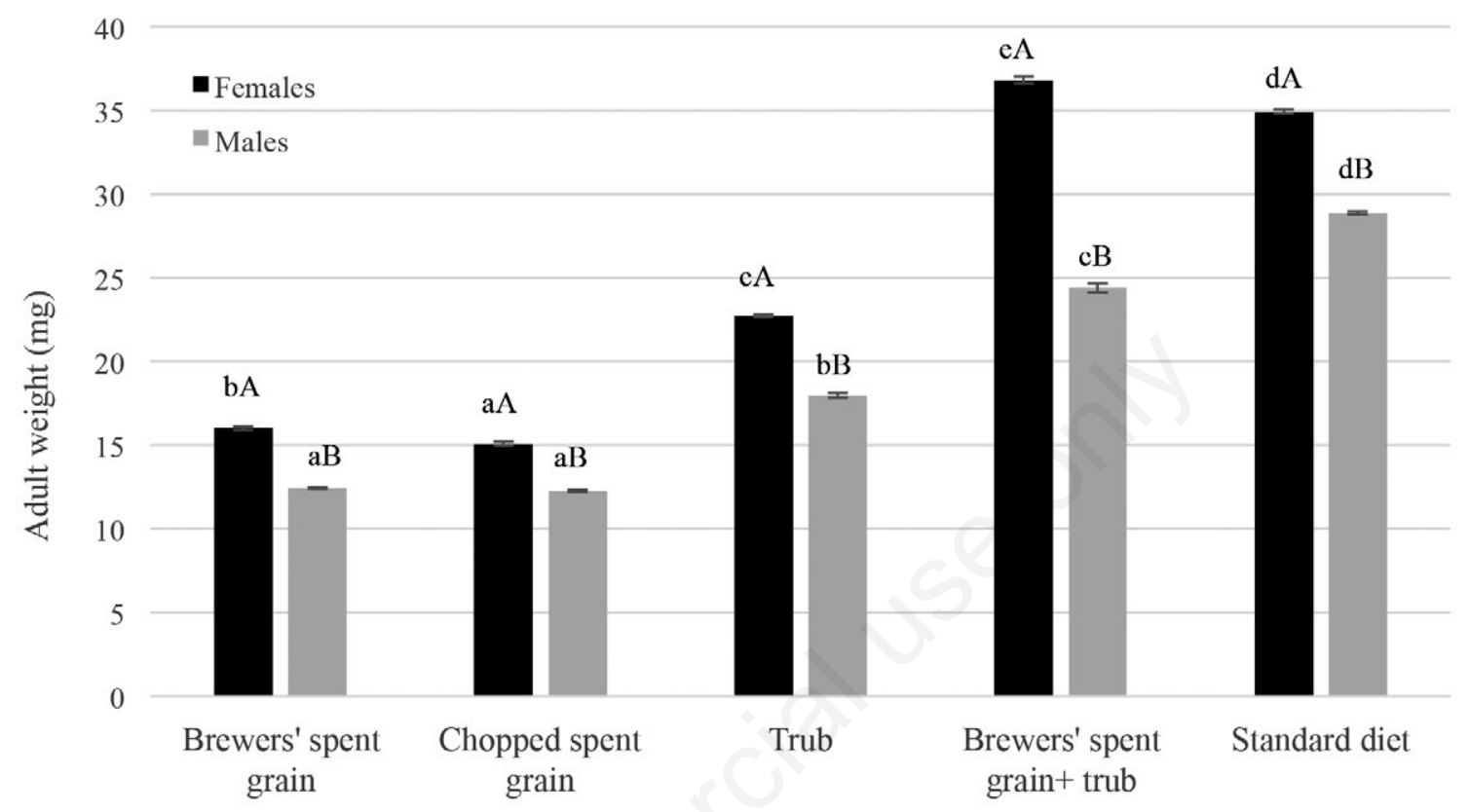

Figure 3. Mean $( \pm S E)$ of female and male weight. Significant differences among means of the different growing substrates are indicated by different lower-case letters (Tukey's test, $\mathrm{P}<0.05)$, while capital letters indicate differences among sexes $(\mathrm{t}$-test, $\mathrm{P}<0.05)$.

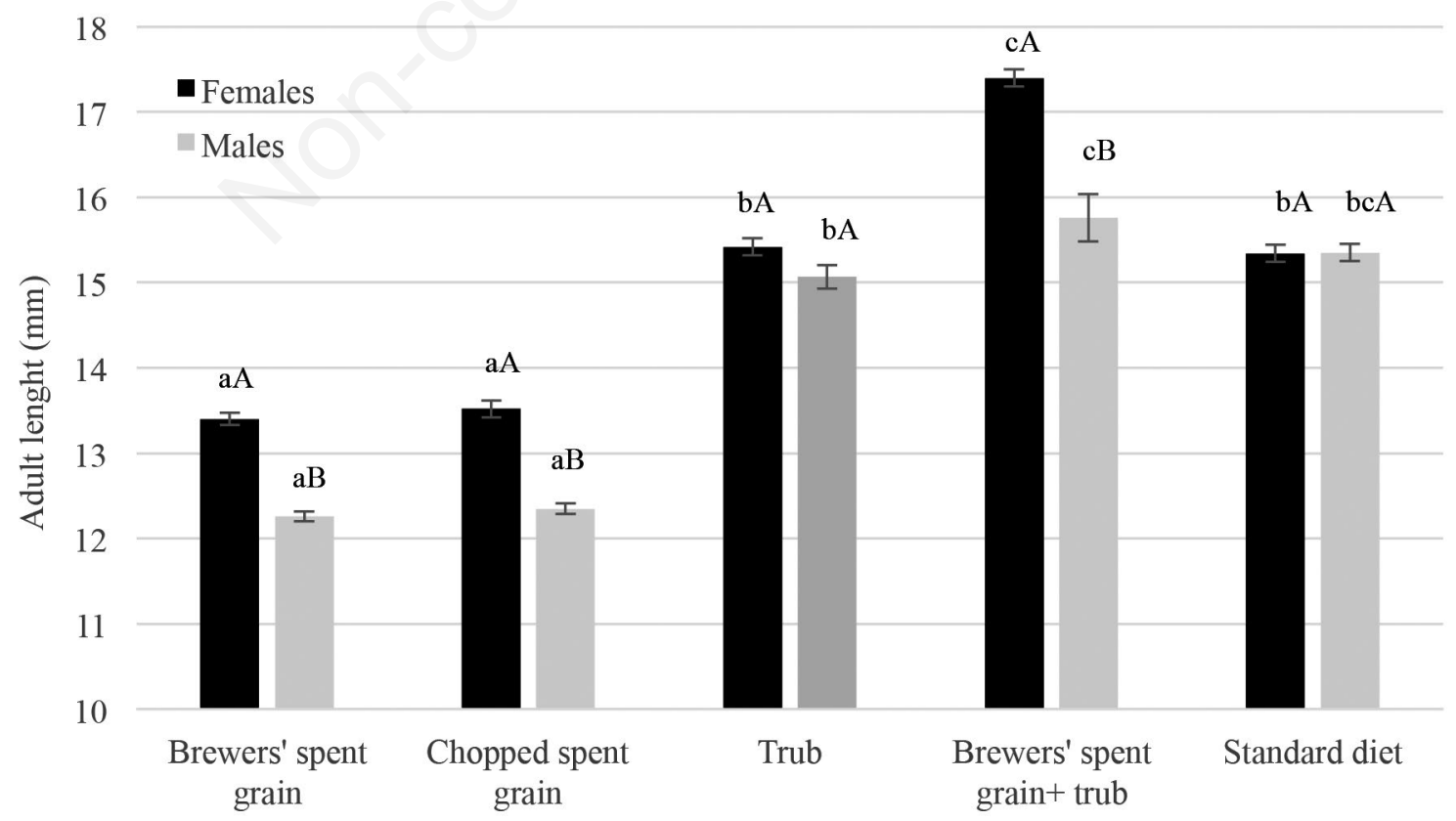

Figure 4. Mean $( \pm \mathrm{SE})$ of female and male lenght. Significant differences among means of the different growing substrates are indicated by different lower-case letters (Tukey's test, $\mathrm{P}<0.05)$, while capital letters indicate differences among sexes $(t-t e s t, P<0.05)$. 
Table 2. Mean $( \pm \mathrm{ES})$ weight of egg clutches and mean number of eggs per clutch deriving from females emerged from the different growing substrates.

\begin{tabular}{|c|c|c|c|c|}
\hline & Egg clutch weight (mg) & & imber & \\
\hline & Mean \pm ES & Mean \pm ES & Min & Max \\
\hline Brewers' spent grain & $8.19 \pm 0.83^{a}$ & $395 \pm 47$ & 209 & 721 \\
\hline Chopped spent grain & $11.18 \pm 1.32^{\mathrm{ab}}$ & $492 \pm 49$ & 207 & 686 \\
\hline Trub & $13.17 \pm 1.49 \mathrm{ab}$ & $581 \pm 44$ & 341 & 791 \\
\hline Brewers' spent grain + trub & $10.05 \pm 1.30^{\mathrm{ab}}$ & $423 \pm 53$ & 206 & 685 \\
\hline Standard diet & $15.29 \pm 1.72^{b}$ & $562 \pm 47$ & 383 & 868 \\
\hline
\end{tabular}

Different letters indicate significant differences across diets $(\mathrm{P}<0.05)$.

al. (2009) underlined that females take more time to develop as they need to accumulate more energy reserves essential for their egg production. Also other insect species show differences in the body dimension between sexes (Lewandowski et al., 2004).

Egg clutches deposit by females emerged from the different diets showed significant differences only in their weight $\left(\mathrm{F}_{4,45}=4.073 ; \mathrm{p}<0.05\right)$, but not on the egg number $\left(\mathrm{F}_{4,45}=2.945\right.$; $\mathrm{P}>0.05$ ) (Table 2). Statistical differences were recorded between the weight of egg clutches of standard diet and brewer's spent grain. Mean number of eggs per clutch varied between 395 (brewers' spaint grain) and 581 (trub), with a minimum value of 206 in the mixture (brewer's spent and trub) and a maximum of 868 in the standard diet (Table 2). Data are in accordance with available literature reporting a mean number of eggs per mass between 120 and 1000 (Booth \& Sheppard, 1984; Tomberlin et al., 2002; Jucker et al., 2017; Barragan-Fonseca et al., 2019; Bertinetti et al., 2019). Adult nutrition influences the longevity, but does not have a direct effect on fertility and egg clutches size and weight. Thus, the difference observed in the egg number could be related to larval dietary content (Barragan-Fonseca et al., 2019; Bertinetti et al., 2019; Lupi et al., 2019).

\section{Conclusions}

This study contributes to investigate the potential applications of the brewery's wastes and adds additional information on the recent interest for brewery by-products as growing substrate for the larvae of H. illucens (Chia et al., 2018; Liu et al., 2018; Bava et al., 2019). The tested substrates sustained the larval development and adult reproduction, showing similar or better performance than other vegetable substrates. In particular, the combined use of the two wastes (brewer's spent grain and trub) provided the best results for all the considered biological traits of $H$. illucens, proving to be a promising rearing substrate for the insect mass production.

In this study we did not considered the nutritional values of the larvae, that is known to be influenced by the diet composition (Barragan-Fonseca et al., 2017), but previous studies on similar substrates referred a protein content of about $50-54 \%$, in line or even higher than the protein content of larvae grown on other vegetable matters (Liu et al., 2018; Bava et al., 2019). Other aspects to be deepened in view of a circular economy application are the waste reduction and the bioconversion efficiency of the brewery's waste, by H. illucens larvae, already partially studied by Bava et al. (2019). Overall, the use of the studied side-streams as larval feeding contributes to create a low-cost growing media and allows to recapture the nutrients that can be recycle in the market as insect proteins for animal feed.

\section{References}

ALIYU S., BALA M., 2011 - Brewer's spent grain: a review of its potentials and applications. - Afr. J. Biotechnol. 10: 324-331.

ASSOBIRRA - Annual report 2018. www.assobirra.it (accessed 20 November 2019).

BARRAGAN-FONSECA K.B., DICKE M., VAN LOON J.J., 2017 - Nutritional value of the black soldier fly (Hermetia illucens L.) and its suitability as animal feed: a review. - J. Insects Food Feed 3: 105-120.

BARRAGÁN-FONSECA K.B., PINEDA-MEJIA J., DICKE M., VAN LOON, J.J., 2018 - Performance of the black soldier fly (Diptera: Stratiomyidae) on vegetable residue-based diets formulated based on protein and carbohydrate contents. - J. Econ. Entomol. 111: 2676-2683.

BARRAGAN FONSECA K.B., GORT G., DICKE M., VAN LOON J.J., 2019 - Effects of dietary protein and carbohydrate on life history traits and body protein and fat contents of the black soldier fly Hermetia illucens. - Physiol. Entomol. 44: 148-159.

BAVA L., JUCKER C., GISLON G., LUPI D., SAVOLDELLI S., ZUCALI M., COLOMBINI S., 2019 - Rearing of Hermetia illucens on Different Organic By-Products: Influence on Growth, Waste Reduction, and Environmental Impact. Animals 9: 289.

BERTINETTI C., SAMAYOA A.C., HWANG S.Y., 2019 - Effects of feeding adults of Hermetia illucens (Diptera: Stratiomyidae) on longevity, oviposition, and egg hatchability: insights into optimizing egg production. - J. Insect Sci. 19: 19.

BOOTH D.C., SHEPPARD C., 1984 - Oviposition of the black soldier by Hermetia illucens (Diptera: Stratiomyidae): eggs, masses, timing and site characteristics. - Environ. Entomol. 13: 421-423.

CAMMACK J., TOMBERLIN J., 2017 - The impact of diet protein and carbohydrate on select life-history traits of the black soldier fly Hermetia illucens (L.) (Diptera: Stratiomyidae). Insects 8: 56.

CAPPELlOZZA, S., LEONARDI, M.G., SAVOLDELLI, S., CARMINATI, D., RIZZOLO, A., CORTELLINO, G., TEROVA G., MORETTO E., BADAILE A., CONCHERI G., SAVIANE A., BRUNO D., BONELLI M., CACCIA S., CASARTELLI M., TETTAMANTI G., 2019 - A first attempt to produce proteins from insects by means of a circular economy. - Animals 9: 278.

CHIA S.Y., TANGA C.M., OSUGA I.M., MOHAMED S.A., KHAMIS F.M., SALIFU D., DICKE M., 2018 - Effects of waste stream combinations from brewing industry on performance of Black Soldier Fly, Hermetia illucens (Diptera: Stratiomyidae). - Peer J 6: e5885. 
DE MARCO I., MIRANDA S., RIEMMA S., IANNONE R., 2016 - Life Cycle Assessment of Ale and Lager Beers Production. Chem. Engin. Transact. 49: 337-342.

DIENER S., ZURBRÜGG C., GUTIÉRREZ F.R., NGUYEN D.H., MOREL A., KOOTTATEP T., TOCKNER K., 2011 Black soldier fly larvae for organic waste treatment-prospects and constraints. - Proc. Waste Safe 2: 13-15.

FAVARO R., LUPI D., JUCKER C., CAPPELLOZZA S., FACCOLI M., 2017 - An artificial diet for rearing three exotic longhorn beetles invasive to Europe. - Bull. Insectol. 70: 91-99.

FILLAUDEAU L., BLANPAIN-AVET P., DAUFIN G., 2006 Water, waste water and waste management in brewering industries. - J. Cleaner Prod. 14: 463-471.

FOWLES M.T, NANSEN C., 2019 - Artificial selection of insects to bioconvert pre-consumer organic wastes. A review. - Agron. Sust. Dev. 39: 31.

GIBBS H.K., RUESCH A.S., ACHARD F., CLAYTON M.K., HOLMGREN P., RAMANKUTTY N., FOLEY J.A., 2010 Tropical forests were the primary sources of new agricultural land in the 1980s and 1990s. - Proc. Natl. Acad. Sci. 107: 16732-16737.

GOBBI P., MARTÍNEZ-SÁNCHEZ A., ROJO S., 2013 - The effects of larval diet on adult life-history traits of the black soldier fly, Hermetia illucens (Diptera: Stratiomyidae). - Eur. J. Entomol. 110: 461-468.

HOC B., NOËL G., CARPENTIER J., FRANCIS F., MEGIDO R.C., 2019 - Optimization of black soldier fly (Hermetia illucens) artificial reproduction. - PloS One 14 (4).

HOLMES L.A., VANLAERHOVEN S.L., TOMBERLIN J.K., 2012 - Relative humidity effects on the life history of Hermetia illucens (Diptera: Stratiomyidae). - Environ. Entomol. 41: 971978.

JONES B.M., TOMBERLIN J.K., 2019 - Impact of Larval Competition on Life-History Traits of the Black Soldier Fly (Diptera: Stratiomyidae). - Ann. Entomol. Soc. Am. 112: 505510.

JUCKER C., ERBA D., LEONARDI M. G., LUPI, D., SAVOLDELLI S., 2017 - Assessment of vegetable and fruit substrates as potential rearing media for Hermetia illucens (Diptera: Stratiomyidae) larvae. - Environ. Entomol. 46: 1415-1423.

JUCKER C., LUPI D., MOORE C.D., LEONARDI M.G., SAVOLDELLI S., 2020 - Nutrient Recapture from Insect Farm Waste: Bioconversion with Hermetia illucens (L.) (Diptera: Stratiomyidae). - Sustainability. Accepted.

KALOVÁ M., BORKOVCOVÁ M., 2013 - Voracious larvae Hermetia illucens and treatment of selected types of biodegradable waste. - Acta Universitatis Agriculturae et Silviculturae Mendelianae Brunensis 61: 77-83.

KERBY C., VRIESEKOOP F., 2017 - An overview of the utilisation of brewery by-products as generated by british craft breweries. - Beverages 3: 24.

LALANDER C., DIENER S., ZURBRÜGG C., VINNERÅS B., 2019 - Effects of feedstock on larval development and process efficiency in waste treatment with black soldier fly (Hermetia illucens). - J. Clean. Product. 208: 211-219.

LEWANDOWSKI M., SZNYK A., BEDNAREK A., 2004 Biology and morphometry of Lycoriella ingenua (Diptera: Sciaridae). - Biol. Lett. 41: 41-50.

LIU Z., MINOR M., MOREL P.C., NAJAR-RODRIGUEZ A.J., 2018 - Bioconversion of three organic wastes by black soldier fly (Diptera: Stratiomyidae) larvae. - Environ. Entomol. 47: 1609-1617.

LUPI D., SAVOLDELLI S., LEONARDI M.G., JUCKER C., 2019 - Feeding in the adult of Hermetia illucens (Diptera
Stratiomyidae): Reality or fiction? - J. Entomol. Acarol. 51: 27-32.

MATHIAS T.R.D.S., ALEXANDRE V.M.F., CAMMAROTA M.C., DE MELLO P.P.M., SÉRVULO E.F.C., 2015 Characterization and determination of brewer's solid wastes composition. - J. Instit. Brewing 121: 400-404.

MENEGUZ M., SCHIAVONE A., GAI F., DAMA A., LUSSIANA C., RENNA M., GASCO L., 2018 - Effect of rearing substrate on growth performance, waste reduction efficiency and chemical composition of black soldier fly (Hermetia illucens) larvae. - J. Sci. Food Agric. 98: 5776-5784.

MIRANDA C.D., CAMMACK J.A., TOMBERLIN J.K., 2019 Life-History traits of the black soldier fly, Hermetia illucens (L.) (Diptera: Stratiomyidae), reared on three manure types. Animals 9: 281.

NAKAMURA S., ICHIKI R.T., SHIMODA M., MORIOKA S., 2016 - Small-scale rearing of the black soldier fly, Hermetia illucens (Diptera: Stratiomyidae), in the laboratory: Low-cost and year-round rearing. - Appl. Entomol. Zool. 51: 161-166.

NEWTON G.L., SHEPPARD D.C., WATSON D.W., BURTLE G.J., DOVE C.R., TOMBERLIN J.K., THELEN E.E., 2005 The black soldier fly, Hermetia illucens, as a manure management/resource recovery tool. - Symposium in the state of the science of Animal Manure and Waste Management, 5-7 January 2005, TX.

NGUYEN T.T.X., TOMBERLIN J.K., VANLAERHOVEN S., 2013 - Influence of resources on Hermetia illucens (Diptera: Stratiomyidae) larval development. - J. Med. Entomol. 50: 898-906

NYAKERI E.M., OGOLA H.J.O., AYIEKO M.A., AMIMO F.A., 2017 - Valorisation of organic waste material: growth performance of wild black soldier fly larvae (Hermetia illucens) reared on different organic wastes. - J. Insects Food Feed 3: 193-202.

OONINCX D.G., DE BOER I.J., 2012 - Environmental impact of the production of mealworms as a protein source for humansa life cycle assessment. - PloS One (12).

ROBERTSON J.A., L'ANSON K.J., TREIMO J., FAULDS C.B., BROCKLEHURST T.F., EIJSINK V.G., WALDRON K.W., 2010 - Profiling brewers' spent grain for composition and microbial ecology at the site of production. - LWT-Food Sci. Technol. 43: 890-896.

ROCHA DOS SANTOS T., MORETISON DE MELLO P.P., CAMPORES SERVILLO E.F., 2014 - Solid wastes in brewing process: a review. - J. Brewing Distilling 5: 1-9.

SHEPPARD D.C., NEWTON G.L., THOMPSON S.A., SAVAGE S., 1994 - A value added manure management system using the black soldier fly. - Biores. Technol. 50: 275-279.

SPRANGHERS T., OTTOBONI M., KLOOTWIJK C., OVYN A., DEBOOSERE S., DE MEULENAER B., ...DE SMET S., 2017 - Nutritional composition of black soldier fly (Hermetia illucens) prepupae reared on different organic waste substrates. - J. Sci. Food Agricult. 97: 2594-2600.

TANG D., YIN G., HE Y., HU S., LI B., LI L., LIANG H., BORTHAKUR D., 2009 - Recovery of protein from brewer's spent grain by ultrafiltration. - Biochem. Eng. J. 48: 1-5.

TINDER A.C., PUCKETT R.T., TURNER N.D., CAMMACK J.A., TOMBERLIN J.K., 2017 - Bioconversion of sorghum and cowpea by black soldier fly (Hermetia illucens (L.) larvae for alternative protein production. - J. Insects Food Feed 3: 121-130.

TOMBERLIN J.K., ADLER P.H., MYERS H.M., 2009 Development of the black soldier fly (Diptera: Stratiomyidae) in relation to temperature. - Environ. Entomol. 38: 930-934.

TOMBERLIN J.K., CAMMACK J.A., 2017 - Black soldier fly: 
biology and mass production. Insects as food and feed: from production to consumption. - Wageningen Academic Publishers, Wageningen, the Netherlands, 230-247.

TOMBERLIN J.K., SHEPPARD D.C., JOYCE J.A., 2002 Selected life history traits of the black soldier fly. - Ann. Entomol. Soc. Am. 95: 379-386.

UNITED NATIONS, 2013 - World Population Prospects: The2012 Revision, Highlights and Advance Tables. - Working Paper No. ESA/P/WP. 228 Department of Economic and Social Affairs, Population Division: New York, NY, USA.
UR REHMAN K., CAI M., XIAO X., ZHENG L., WANG H., SOOMRO A.A., ZHOU Y., LI W., YU Z., ZHANG J., 2017 Cellulose decomposition and larval biomass production from the co-digestion of dairy manure and chicken manure by minilivestock (Hermetia illucens L.). - J. Environ. Manag. 196: 458-465.

VARELAS V., 2019 - Food Wastes as a Potential New Source for Edible Insect Mass Production for Food and Feed: A review. Fermentation 5: 81 . 